\title{
Energy balance and efficiency in crop rotation systems
}

\section{Balanço e eficiência energética em sistemas de rotação de culturas}

\author{
Henrique Giordani Martini Ferreira1*; Ivan Bordin²; Osmar Maziero Buratto3; \\ Laíse da Silveira Pontes ${ }^{4}$
}

\section{Highlights}

Energy balance in crop succession and rotation systems is positive.

Corn has a high energy balance and efficiency.

Crop rotation systems should be preferred due to their environmental conservation.

\section{Abstract}

The production system model that has been adopted in most Brazilian regions, the soybean/second corn crop succession, has led to problems in water and soil conservation and favorable conditions for diseases, pests, and weeds in the agricultural system and, consequently, increasing its energy use. Crop rotation is an alternative to this production model, directly interfering with the problematic aspects of the crop succession system and, consequently, its energy balance. Therefore, this study aimed to identify the crop rotation system with the best energy balance and efficiency. The data on the quantity of inputs (seeds, fertilizers, pesticides, and fuel), labor, and grain yield used in the study were collected from a crop rotation experiment conducted at the experimental station of the Rural Development Institute of Paraná - IAPAR-EMATER, Londrina, PR, Brazil, from 2014 to 2020. The experimental design consisted of randomized blocks, with six treatments and four replications. The treatments consisted of T1 (second corn crop/soybean), T2 (white oat/ soybean, triticale/corn, and wheat/soybean), T3 (rye + black oat/soybean, black oat + fodder radish/corn, and congo grass/soybean), T4 (canola/corn, crambe/corn; canola/soybean); T5 (buckwheat-fodder radish/ corn, bean/soybean, and buckwheat-white oat/ soybean), and T6 (wheat/corn, canola/corn + congo grass, and bean/soybean). The different crop rotations and the traditional second corn crop/soybean system provided positive energy balance and efficiency, that is, they produced more energy than they consumed. The canola/corn, crambe/corn, and canola/soybean rotation systems had the highest energy balance and efficiency, with values of $866,442.27 \mathrm{MJ} \mathrm{ha}^{-1}$ and 10.27 , respectively, mainly due to corn cultivation in the summer, which resulted in a higher energy return than the other grain-producing crops.

Key words: Conservation agriculture. Crop diversification. Crop succession. Energy balance. Energy in agriculture.

1 MSc in Conservation Agriculture, Instituto de Desenvolvimento Rural do Paraná, IDR-Paraná, IAPAR-Emater, Londrina, PR, Brazil. E-mail: henriquegiordane@hotmail.com

2 Researcher, IDR-Paraná, IAPAR-Emater, Londrina, PR, Brazil. E-mail: ivanbordin@idr.pr.gov.br

3 Agronomist, Cocamar Cooperativa Agroindustrial, Cambé, PR, Brazil. Email: osmarburatto11@gmail.com

${ }^{4}$ Researcher, IDR-Paraná, IAPAR-Emater, Ponta Grossa, PR, Brazil. E-mail: laisepontes@idr.pr.gov.br

* Author for correspondence

Received: May 12, 2021 - Approved: Aug. 09, 2021 


\section{Resumo}

O modelo de sistema de produção que vem sendo adotado na maioria das regiões brasileiras, a sucessão de soja/milho segunda safra, é um sistema que vem acarretando problemas na conservação da água e dos solos, e também levando a condições favoráveis para doenças, pragas e plantas daninhas no sistema agrícola e consequentemente elevando o uso de energia no sistema. A alternativa para esse modelo de produção é a rotação de cultura, no qual, pode interferir diretamente nos pontos problemáticos do sistema de sucessão de culturas e consequentemente no balanço de energia dos sistemas. Portanto, o objetivo do presente estudo é identificar o sistema de rotação de culturas, com melhor balanço e eficiência energética. Os dados de quantidade de insumos (sementes, adubos, defensivos e combustível), mão de obra homem e rendimento de grãos utilizados no estudo, foram coletados de um experimento de rotação de culturas conduzido na estação experimental do Instituto de Desenvolvimento Rural do Paraná - IAPAR-EMATER, Londrina-PR, durante os anos de 2014 a 2020. O delineamento experimental utilizado foi o de blocos ao acaso, com seis tratamentos e quatro repetições. Os tratamentos do experimento são: T1 (milho segunda safra/soja); T2 (aveia branca/soja; triticale/milho; trigo/soja); T3 (centeio + aveia preta/soja; aveia preta + nabo forrageiro/milho; braquiária/soja); T4 (canola/milho; crambe/milho; canola/soja); T5 (trigo mourisco - nabo forrageiro/milho; feijão/soja; trigo mourisco - aveia branca/soja) e T6 (trigo/milho; canola/milho + braquiária; feijão/soja). As diferentes rotações, bem como o sistema tradicional milho segunda safra/ soja, proporcionaram balanço e eficiência energética positiva, ou seja, produziram mais energia do que consumiram. O sistema de rotação com canola/milho; crambe/milho; canola/soja apresentou o maior balanço e maior eficiência energética, com 866.442,27 MJ ha-1 e 10,27, respectivamente, em decorrência principalmente do cultivo do milho no verão, que resultou maior retorno energético em relação às demais culturas produtoras de grãos.

Palavras-chave: Agricultura conservacionista. Balanço energético. Diversificação de culturas. Energia na agricultura. Sucessão de culturas.

\section{Introduction}

The input of energy into a production system depends on the degree of its management. Stages such as soil correction, sowing, agricultural machinery, and inputs required to control weeds, diseases, and pests represent different energy expenditures of a production system.

The use of energy balance in agriculture can be a tool for the decision of new management techniques in the system, providing energy savings. Thus, the energy analysis of the system is important for planning the agricultural activity, portraying in the best way the context of sustainability of production units. Energy balance is defined as an instrument to account for the available energy and the energy consumed in a given production system, allowing its intervention, aiming to improve efficiency (Santos, Tomm, Spera, \& Ávila, 2007).

The productionsystemadopted in most Brazilian regions is the soybean/second corn crop succession, which leads to higher ease in the planning, mechanization, credits, and commercialization of the final production. It is a system preferably conducted using chemical fertilizers, fuels, fungicides, herbicides, and insecticides, which are non-renewable 
energies. This system has been causing problems in water and soil conservation and leading to favorable conditions for diseases, pests, and weeds in the agricultural system (Santos \& Simon, 2010).

Crop rotation is an alternative to this production model, as it consists of alternating different crops within the agricultural system in a regular sequence. The model is composed of cover crops or green manure, such as signalgrass, white oat, fodder radish, lupin, vetch, and millet, and plants that can generate income for the farmer, such as wheat, white oat, sorghum, and corn. The rotation aims to diversify the income, control or reduce the incidence of weeds, pests, and diseases, minimal soil disturbance, and maintenance of soil organic matter and, consequently, soil fertility (Medeiros \& Calegari, 2006). These characteristics can directly interfere with the energy balance of the system, reducing the use of herbicides, insecticides, fungicides, and chemical fertilizers, especially nitrogen. These practices are indispensable for the development of stable agriculture in terms of sustainability.

Santos, Ignaczak, Lhamby and Baier (2000a), Santos, Ignaczak, Lhamby and Carmo (2003), Santos et al. (2007), Santos, Spera, Fontaneli and Dreon (2011), showed that crop rotation systems are more energy-efficient and should be preferred instead of crop succession. The authors observed that cover crops tend to have a low energy performance, reducing the input of fossil energy into the systems. They also reported that corn has a higher energy return than wheat and soybean, compensating for the low energy performance of cover crops in crop rotation systems. These studies confirmed that crop rotation can reduce energy input and be more energyefficient than crop succession systems. Also, these studies were developed using cover crops, regions, climates, altitudes, and soils different from those used in the present study, which was carried out in the city of Londrina, PR, Brazil.

The traditional grain production system used in the Londrina region is the soybean/ second corn crop succession. This study was based on the hypothesis that there are crop rotation systems that are more energy efficient compared to the traditional soybean/ second corn crop succession system.

Therefore, this study aimed to identify the crop rotation system with higher energy balance and efficiency.

\section{Material and Methods}

The study was carried out at the experimental area of the Rural Development Institute of Paraná - IAPAR-EMATER (IDRParaná), located in Londrina, PR, Brazil, under the geographic coordinates $23^{\circ} 22^{\prime} \mathrm{S}$ and $51^{\circ} 10^{\prime} \mathrm{W}$, with an altitude of $585 \mathrm{~m}$. The soil is classified as an Oxisol (Santos et al., 2018). The regional climate is classified as $\mathrm{Cfa}$ according to Köppen, that is, a humid subtropical climate with an average annual temperature of 20.5 ${ }^{\circ} \mathrm{C}$ and an average annual rainfall of $1700 \mathrm{~mm}$ (Nitsche, Caramori, Rice, \& Pinto, 2019).

The experiment was conducted under two cycles of three years of crop rotation, from 2014 to 2017 and 2017 to 2020. The experimental design was randomized blocks, with six treatments and four replications, consisting of a plot of $300 \mathrm{~m}^{2}(15 \times 20 \mathrm{~m})$. 
The treatments were as follows: T1 - second corn crop/soybean, second corn crop/soybean, and second corn crop/soybean (2014 to 2017); second corn crop/soybean, second corn crop/soybean, and second corn crop /soybean (2017 to 2020); T2 - white oat/ soybean, rye/corn, and wheat/soybean (2014 to 2017); white oat/soybean, triticale/corn, and wheat/soybean (2017 to 2020); T3 - rye + black oat/soybean, black oat + fodder radish/ corn, and congo grass /soybean (2014 to 2017); rye + black oat/soybean, black oat + fodder radish/ corn, and brachiaria/soybean (2017 to 2020); T4 - canola/corn, crambe/corn, and safflower/ soybean (2014 to 2017); canola/corn, crambe/ corn, and canola/soybean (2017 to 2020); T5 buckwheat/fodder radish/corn, bean/soybean, and buckwheat/white oat/soybean (2014 to 2017); buckwheat/fodder radish/corn, bean/ soybean, and buckwheat/white oat/soybean (2017 to 2020); and T6 - wheat/corn + congo grass, canola/corn + congo grass, and bean/ soybean (2014 to 2017); wheat/corn, canola/ corn + signalgrass, and bean/soybean (2017 to 2020$)$.

All energy inputs used in each system, that is, the quantity of seeds for each crop, fertilizers (nitrogen, phosphorus, and potassium), pesticides (herbicides, insecticides, and fungicides), fuel (diesel, lubricant, and grease), and labor for each management carried out during the six years of crop rotation, were added to evaluate the energy balance and efficiency indices. In addition, all energy outputs from the systems, that is, the grain yield of each crop, were also added.

The energy units of each system were transformed from $\mathrm{kg}, \mathrm{L}$, and hours ha-1 into $\mathrm{MJ}$ $\mathrm{ha}^{-1}$, used as a standard unit to compare all the indices. A literature review was carried out to survey these energy units. The energy values in $\mathrm{MJ} \mathrm{kg}{ }^{-1}$ adopted for the crop seeds used in the experiment were: 33.22 (corn) (Riquetti, Benez, \& Silva, 2012), 31.85 (soybean), 17.25 (white and black oats) (Santos, Ignaczak, Lhamby \& Zoldan 2000b), 15.50 (wheat), 15.60 (rye), 33.60 (bean), 1.51 (fodder radish) (Marchioro, 1985), 27.4 (crambe) (Jasper, Biaggioni, Silva, Seki, \& Bueno, 2010), 29.43 (canola) (Khakbazan et al., 2019), 16.26 (triticale) (Fialho \& Albino, 1983), 1.44 (buckwheat) (U. S. Department of Agriculture [USDA], 2019), 10.50 (signalgrass), and 21.45 (safflower), estimated by the Laboratory of Food Analysis of the State University of Londrina (UEL).

The adopted fertilizer indices consisted of the values presented by Bueno (2002), that is, $62.70 \mathrm{MJ} \mathrm{kg}^{-1}$ of $\mathrm{N}, 9.66 \mathrm{MJ} \mathrm{kg}^{-1}$ of $\mathrm{P}_{2} \mathrm{O}_{5}$, and $9.24 \mathrm{MJ} \mathrm{kg}^{-1}$ of $\mathrm{K}_{2} \mathrm{O}$. The indices for pesticides were $347.65 \mathrm{MJ} \mathrm{kg}^{-1}$ for herbicides and 309.62 $\mathrm{MJ} \mathrm{kg}{ }^{-1}$ for insecticides (Pimentel, 1980). The caloric value of $271.96 \mathrm{MJ} \mathrm{kg}^{-1}$ was used for fungicides (Pimentel, Bernard, \& Fast, 1983 apud Santos, 2006).

Values of $38.47,39.56$, and 43.52 $\mathrm{MJ} \mathrm{kg}{ }^{-1}$ were adopted as energy indices for fuel, lubricating oil, and grease, respectively (Bueno, 2002). Diesel consumption for sowing operation was estimated using the method adopted by the American Society of Agricultural Engineers [ASAE] (2003). The estimated power demand on the tractor drawbar was calculated by Equations 1, 1.1, and 1.2. The machinery used in the experiment were: i) Jhon Deere 7515 tractors, with a nominal engine power of $140 \mathrm{hp}(103 \mathrm{~kW}) ;$ ii) NW TL 75-E, with a nominal engine power of 75 hp (55.2 kW); iii) Kuhn PDN-PG 9000 seed drills, with nine rows for coarse grains and 
ridger working at a depth of approximately 7 $\mathrm{cm}$; iv) Semeato 11/13, with 13 rows for small grains; v) Jacto Condor AMI4 sprayer with a 600-L tank and 12-meter boom; vi) Cremasco 90 fertilizer spreader, with a working width of $12 \mathrm{~m}$; vii) knife roller, manufactured by the Department of Agricultural Engineering of IDRParaná, with a working width of $2 \mathrm{~m}$; and viii) NW TC5090 harvester, with a nominal engine power of $258 \mathrm{hp}(189 \mathrm{~kW})$.

$$
\mathbf{P d b}=[(\mathbf{R b}+\mathbf{R t}) \times \mathrm{S}] / 1000
$$

where $\mathrm{Pdb}$ is the drawbar power $(\mathrm{kW}), \mathrm{Rb}$ is the tractor bearing resistance $(\mathrm{N})$, Rt is the machine total traction resistance $(\mathrm{N})$, and $\mathrm{S}$ is the speed $\left(\mathrm{m} \mathrm{s}^{-1}\right)$.

$$
\mathbf{R b}=\mathbf{K b} \times \mathbf{W}
$$

where $\mathrm{Rb}$ is the tractor bearing resistance $(\mathrm{N})$, $\mathrm{Kb}$ is the bearing resistance coefficient $(0.10$ to 0.12 ), and $\mathrm{W}$ is the total tractor weight $(\mathrm{N})$.

\section{$R t=R c+R d+R s$}

where $\mathrm{Rt}$ is the machine total traction resistance $(\mathrm{N}), \mathrm{Rc}$ is the machine traction resistance $(\mathrm{N}), \mathrm{Rd}$ is the land declivity $(270 \mathrm{~N})$, and Rs is the soil surface conditions $(210 \mathrm{~N})$.

$$
\mathbf{R c}=\mathbf{R c u} \times \mathbf{n}
$$

where Rc is the machine traction resistance $(\mathrm{N})$, Rcu is the resistance per ridger $(\mathrm{N})$, and $\mathrm{n}$ is the number of ridgers.

$$
\text { Rcu }=\mathbf{j} \times \mathbf{d}
$$

where Rcu is the resistance per ridger $(N), j$ represents a clay soil (175 to 280 ), and $d$ is the working depth $(\mathrm{cm})$.
Moreover, a loss relative to the tractor power transfer is equal to 0.73 , a loss of engine power according to the altitude and temperature of the experimental region equal to 0.91 , and a machine age equal to 0.85 were considered to calculate the estimated power demand on the drawbar (ASAE, 2003). The fuel consumption per hectare (Equation 2) and the operating fuel consumption (Equation 3) were calculated considering the consumption of 0.25 liters per hour for each horsepower (hp) required by the tractor (Pacheco, 2000).

$$
\mathrm{Fc}=\mathrm{Pdb} \times 0.25
$$

where $\mathrm{Fc}$ is the fuel consumption $\left(\mathrm{L} \mathrm{ha}^{-1}\right)$ and $\mathrm{Pdb}$ is the drawbar power (cv).

\section{$\mathrm{Co}=\mathrm{Fc} / \mathrm{FCe}$}

where $\mathrm{Co}$ is the operating fuel consumption ( $\mathrm{L}$ $\left.\mathrm{ha}^{-1}\right), \mathrm{Fc}$ is the fuel consumption $\left(\mathrm{L} \mathrm{ha}^{-1}\right)$, and $\mathrm{FCe}$ is the effective field capacity $\left(\mathrm{ha}^{-1}\right)$.

$$
F C t=(W \times S) / 10
$$

where FCt is the theoretical field capacity (ha $\left.\mathrm{h}^{-1}\right), \mathrm{W}$ is the working width (m), and $\mathrm{S}$ is the working speed $\left(\mathrm{km} \mathrm{h}^{-1}\right)$.

$$
\mathrm{FCe}=\mathrm{FCt} \times \mathrm{Ef}
$$

where FCe is the effective field capacity (ha $\mathrm{h}^{-1}$ ), FCt is the theoretical field capacity (ha $\left.\mathrm{h}^{-1}\right)$, and $\mathrm{Ef}$ is the field efficiency (decimal).

The field efficiency used for each set was 0.70 for Jhon Deere tractor and Kuhn seed drill, 0.90 for NW75 tractor and Semeato, 0.70 for NW75 and Jacto sprayer, 0.90 for NW75 and knife roller, 0.70 for NW75 and fertilizer 
spreader, and 0.70 for NW TC5090 (Pacheco, 2000).

The Romanelli (2002) method was used for the harvester fuel consumption, according to Equation 4.

\section{$\mathrm{Fc}=\mathrm{Po} \times \mathrm{Fec}$}

(4)

where $\mathrm{Fc}$ is the hourly fuel consumption $\left(\mathrm{L} \mathrm{h}^{-1}\right)$, $\mathrm{Po}$ is the gross engine power (KW), and Fec is the specific consumption factor per power $\left(0.163 \mathrm{~L} \mathrm{KW}^{-1} \mathrm{~h}^{-1}\right)$.

The calculation of grease used in the seed drills considered $5 \%$ fuel consumption (Müller et al., 2017), while the lubricating useful life was used as informed by the manufacturer of each machine.

The labor was calculated according to the amount of work carried out during sowing, spraying, broadcast fertilization, knife roller operation, and harvesting. Mean energy consumption of $0.22 \mathrm{MJ} \mathrm{h}^{-1}$ was considered to calculate the energy expenditure by machine operators in the various operations carried out during all the experimental years (Assenheimer, Campos, \& Gonçalvez Júnior, 2009). The energy output considered the crop grain production, transformed according to their energy coefficients ( $\mathrm{MJ} \mathrm{kg}^{-1}$ ): 16.61 (corn) (Riquetti et al., 2012), 16.80 (soybean), 15.70 (white oat), 14.15 (bean) (Marchioro, 1985), 12.61 (wheat) (Santos et al., 2000b), 27.4 (crambe) (Jasper et al., 2010), 29.43 (canola) (Khakbazan et al., 2019), 16.26 (triticale) (Fialho \& Albino, 1983), 1.44 (buckwheat) (USDA, 2019), and 21.45 (safflower), estimated by the Laboratory of Food Analysis of UEL.
The Risoud (1999) method was adopted for the energy analysis based on the energy input and output indices transformed into MJ. The relationship indices between sustainability and energy analysis of agricultural exploitation, which consist of the energy balance and efficiency, are shown in Equations 5 and 6.

Energy balance $=\Sigma$ total energy of produced products $-\Sigma$ non-renewable energy inputs (5)

Energy efficiency $=\Sigma$ total energy of produced products / $\Sigma$ non-renewable energy inputs (6)

\section{Results and Discussion}

Table 1 shows the sums of energy inputs in each system studied during the six years of crop rotation. The highest energy input was found in T6, with a value of $107,765.08 \mathrm{MJ}$ $\mathrm{ha}^{-1}$, followed by T2, with a value of $100,624.11$ MJ ha-1, T4 with 93,445.08 MJ ha ${ }^{-1}$, T1 with 91,058.46 MJ ha-1, T5 with 85,246.76 $\mathrm{MJ} \mathrm{ha}^{-1}$, and T3 with 58,792.58 MJ ha-1. The highest energy proportions in T6, T2, T4, T1, and T5 occurred because summer and winter crops demand more phytosanitary management for grain production. The lower input proportion in T3 during the six years of crop rotation occurred because this system uses soil cover crops during winter cultivation, and these crops required a low use of fungicides, herbicides, and insecticides, as well as the non-application of formulated fertilizers. These facts can be better understood when the quantity of inputs that each treatment used was detailed (Figure 1). 
Table 1

Total energy inputs (MJ ha-1) in the six Years of crop rotation. Londrina-PR

\begin{tabular}{cc} 
Treatments & Energy inputs $\left(\mathbf{M J ~ h a}^{-1}\right)$ \\
\hline T1 & $91,058.46$ \\
T2 & $100,624.11$ \\
T3 & $58,792.58$ \\
T4 & $93,445.08$ \\
T5 & $85,246.76$ \\
T6 & $107,765.08$ \\
\hline
\end{tabular}

Figure 1 shows the quantity of inputs in each treatment during the six years of the experiment, considering all inputs in $\mathrm{MJ} \mathrm{ha}^{-1}$. All types of energy were grouped, namely: labor, seeds, diesel, lubricant, chemical fertilizers $\left(\mathrm{N}, \mathrm{K}_{2} \mathrm{O}\right.$, and $\left.\mathrm{P}_{2} \mathrm{O}_{5}\right)$, and pesticides (herbicides, fungicides, and insecticides). N stands out with the highest energy expenditure in the treatments, that is, representing $31,045.91$, 39,602.57, 16,120.26, 48,986.59, 27,779.86, and 51,301.86 $\mathrm{MJ} \mathrm{ha}^{-1}$ in T1, T2, T3, T4, T5, and T6, respectively (Figure 1). T3 presented the lowest $\mathrm{N}$ proportion due to the non-use of nitrogen fertilizers in soil cover crops. On the other hand, $\mathrm{T} 2, \mathrm{~T} 4$, and $\mathrm{T} 6$ had a higher $\mathrm{N}$ proportion during the six years, representing almost half of the energy used for production. These treatments have corn cultivation in the summer, with a higher investment of topdressing nitrogen fertilization in the corn crop. Moreover, crops planted during the winter under these treatments also used topdressing nitrogen fertilization, such as white oat, triticale, and wheat in T2, canola and crambe in T4, and wheat, canola, and bean in T6.
Diesel is one of the three energy expenditures with the highest proportion in the production, representing 17,069.64 $\mathrm{MJ}$ $\mathrm{ha}^{-1}$ in T1, 13,556.46 MJ ha ${ }^{-1}$ in T2, 10,995.04 MJ ha-1 T3, 14,005.34 MJ ha-1 in T4, 15,876.18 $\mathrm{MJ} \mathrm{ha}{ }^{-1}$ in T5, and $14,957.88 \mathrm{MJ} \mathrm{ha}^{-1}$ in T6 (Figure 1). Together, these two forms of energy ( $\mathrm{N}$ and diesel) represent $53 \%$ in $\mathrm{T} 1,54 \%$ in $\mathrm{T} 2$, $46 \%$ in $\mathrm{T} 3,67 \%$ in $\mathrm{T} 4,52 \%$ in $\mathrm{T} 5$, and $62 \%$ in T6, that is, approximately half of the energy used for production.

Studies developed by other authors in regions, management practices, and systems different from those studied here have shown similar results regarding the higher energy expenditure for $\mathrm{N}$ and diesel. Medeiros (2011) conducted a study in the region of Lucas do Rio Verde, MT, Brazil, and observed that diesel presented participation of 2,416.2 $\mathrm{MJ}$ ha $^{-1}(28.76 \%)$ in soybean production and $2,197 \mathrm{MJ} \mathrm{ha}^{-1}$ (30.05\%) in corn production, with the highest contribution of energy input. Moreover, $\mathrm{N}$ had a participation of $938 \mathrm{MJ}^{-1}$ (13\%) in corn production, being the second form of energy that most entered the system, only behind the diesel. 


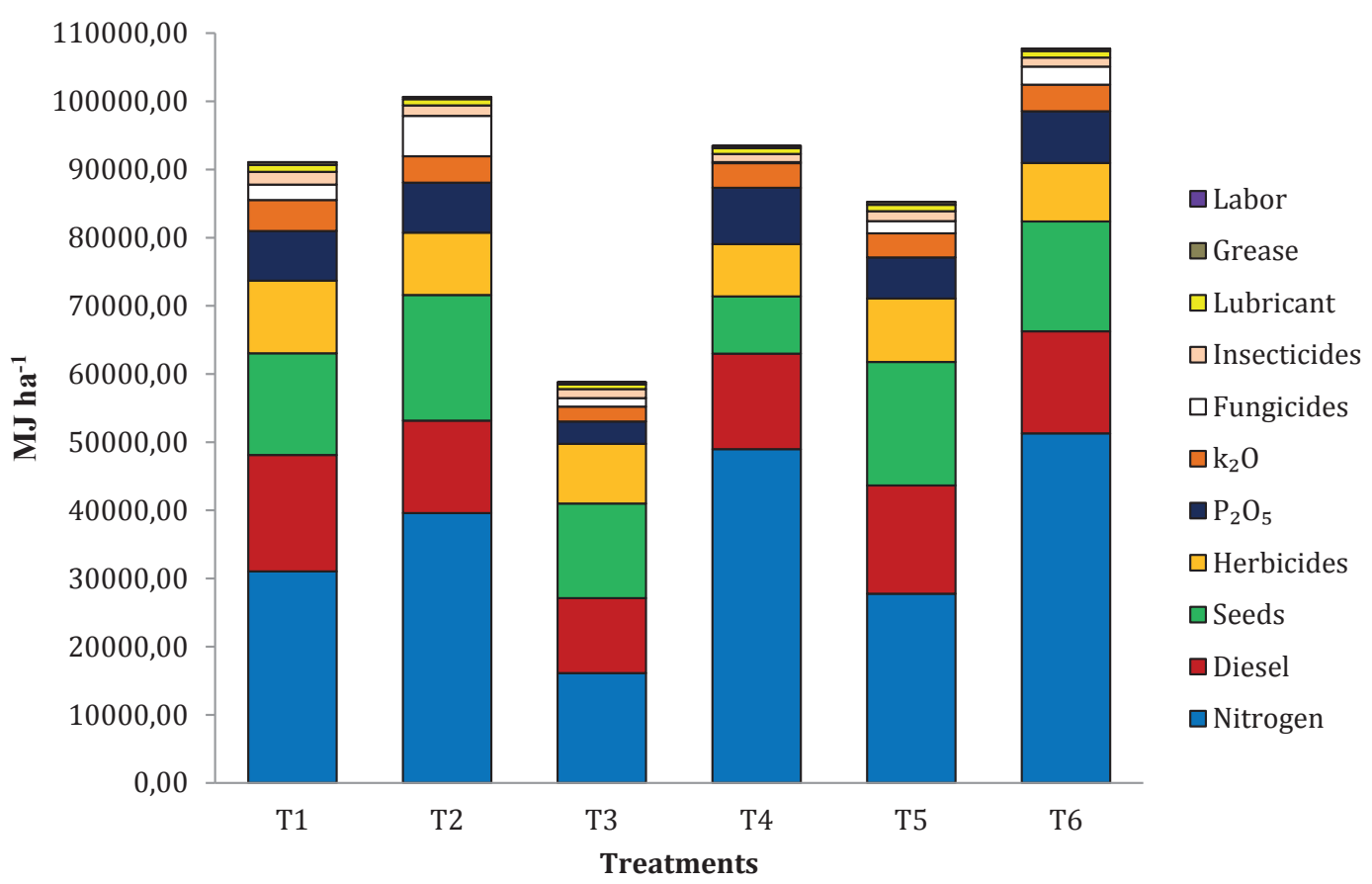

Figure 1. Input share (MJ ha-1) for again production from tratments during the six Years of crop rotation.

Santos (2006) carried out a study in Itaberá, SP, Brazil, and found that diesel presented participation of 2,418.68 $\mathrm{MJ} \mathrm{ha}^{-1}$ (28.06\%) in the energy input into the corn production system under no-tillage, being only smaller than the input of fertilizers, as $\mathrm{N}$ accounted for the highest part, that is, 3,182.37 MJ ha-1 (83\%). Jasper et al. (2010) also observed that the highest energy consumption in a crambe production system under notillage in the region of Botucatu, SP, Brazil, reached 1,000.16 $\mathrm{MJ} \mathrm{ha}^{-1}$ (24.16\%) for $\mathrm{N}$ and $953 \mathrm{MJ} \mathrm{ha}^{-1}$ (23.04\%) for diesel. The high diesel consumption in the treatments, associated with the low value of the labor, demonstrates that the production systems are more technified, with a high degree of mechanization and people only to control the machines.

Seeds and herbicides were other forms of energy that had great prominence. Seeds represented, during the six years of crop rotation, 14,914.10 $\mathrm{MJ} \mathrm{ha}^{-1}$ (16\%) in T1,
18,427.63 $\mathrm{MJ} \mathrm{ha}^{-1}(18 \%)$ in T2, 13,882.78 MJ $\mathrm{ha}^{-1}(24 \%)$ in T3, 8,394.31 MJ ha-1 $(9 \%)$ in T4, $18,120.96 \mathrm{MJ} \mathrm{ha}^{-1}(21 \%)$ in T5, and 16,107.76 MJ ha-1 (14\%) in T6. The high value of energy expenditure of the seeds is due to the high values of their energy coefficients, especially soybean (32.85 MJ kg-1), corn (33.22 MJ $\mathrm{kg}^{-1}$ ), bean (33.60 MJ kg-1), and canola seeds (29.43 MJ kg-1). Herbicides accounted for the fourth-highest total energy expenditure in the treatments, with the highest participation among pesticides (Figure 1). Herbicides represented total energy of $10,6667.50 \mathrm{MJ}$ $\mathrm{ha}^{-1}(12 \%), 9,144.98 \mathrm{MJ} \mathrm{ha}^{-1}(9 \%), 8,769.12 \mathrm{MJ}$ $\mathrm{ha}^{-1}(15 \%), 7,674.03 \mathrm{MJ} \mathrm{ha}^{-1}(8 \%), 9294.08 \mathrm{MJ}$ $\mathrm{ha}^{-1}(11 \%)$, and 8,582.09 $\mathrm{MJ} \mathrm{ha}^{-1}(10 \%)$ for T1, $\mathrm{T} 2, \mathrm{~T} 3, \mathrm{~T} 4, \mathrm{~T} 5$, and $\mathrm{T} 6$, respectively.

Santos (2006) found that pesticides contributed with $1,612.99 \mathrm{MJ} \mathrm{ha}^{-1}$ (18.7\%) and seeds with $503.97 \mathrm{MJ} \mathrm{ha}^{-1}$ (5.84\%) of the total energy of a corn production system, with pesticides being the third and seeds the 
fourth largest expenditure of energy. Campos, Klosowsk, Souza, Zaninu and Prestes (2009) studied the energy balance of soybean production under no-tillage in Medianeira, PR, Brazil, and found that the energy consumption of herbicides represented $758.47 \mathrm{MJ}$ ha-1 $^{-1}$ $(22.6 \%)$ of the total energy of the system. This input was among the three highest energy expenditures, only behind diesel $(1,021.71$ MJ ha ${ }^{-1}$ and $29.43 \%$ ) and seeds (937.22 MJ ha $^{-1}$ and 27.50\%). Ferreira, Neumann and Hoffmann (2014) observed that pesticides had participation of $624.17 \mathrm{MJ} \mathrm{ha}^{-1}$ (5.48\%) in wheat grown in Rio Grande do Sul, Brazil, being $311.15 \mathrm{MJ} \mathrm{ha}^{-1}$ (49.85\%) related to the use of herbicide, which was the fourth largest expenditure of energy within the system, behind fertilizers, fuels, and seeds.

Therefore, energy expenditures from nitrogen, fuels, seeds, and herbicides represent most of the energy consumption in production systems even in studies with isolated crops or crop rotation. According to
Bueno (2002), high grain yields are obtained when using the so-called Green Revolution tripod, which means: improved seeds, a high degree of mechanization, and chemical inputs, as they are the basis of current agricultural systems.

Table 2 represents the total energy output that each treatment obtained during the six years of crop rotation. Treatment T4 had the highest energy output, with a value of 959,887.35 MJ ha-1, followed by T6 with 933,729.47 MJ ha ${ }^{-1}$. The highest energy output in T4 and T6 occurred because the two systems had four corn cultivations in the summer during the six years of crop rotation, with high yields, increasing the energy output index of these systems. The lowest energy output in T3 during the six years of crop rotation occurred because this system uses soil cover crops in the winter cultivation. These crops are not harvested and, therefore, there is no energy output, causing the energy output index to be lower among the treatments.

\section{Table 2}

Total energy outputs ( $\mathrm{MJ} \mathrm{ha}^{-1}$ ) in the six Years of crop rotation. Londrina-PR

\begin{tabular}{|cc|}
\hline Treatments & Energy outputs $\left(\mathbf{M J} \mathbf{~ h a}^{-1}\right)$ \\
\hline T1 & $877,381.15$ \\
T2 & $836,436.39$ \\
T3 & $587,100.01$ \\
T4 & $959,887.35$ \\
T5 & $675,301.09$ \\
T6 & $933,729.47$ \\
\hline
\end{tabular}

Energy outputs are linked to the grain yield of the crops used in this study, which are shown in Table 3. Treatment 1 shows that the second corn crop in 2016 and 2019 had a yield of 2,737 and $2,312 \mathrm{~kg} \mathrm{ha}^{-1}$, respectively, mean yields below those obtained in the state of Paraná for the same crops, which reached values of 5,457 and 5,012 $\mathrm{kg} \mathrm{ha}^{-1}$, respectively (Companhia Nacional de Abastecimento [CONAB], 2021). However, the mean yield of the second corn crop in the state of Paraná from 2014 to 2020 was 5,309 $\mathrm{kg} \mathrm{ha}^{-1}$ (CONAB, 2021), while the mean yield of the second corn crop of treatment 1 during the same period was 
$5,216 \mathrm{~kg} \mathrm{ha}^{-1}$, showing that the low yield from 2016 and 2019 was not a factor that interfered with the energy output of the system. It also demonstrated that the energy output of this system remained high due to the yields of the second corn crop, which are much higher than the yields of other crops grown in the winter for the other treatments. According to CONAB
(2021), the mean soybeans yield in the state of Paraná from 2014 to 2020 was $3,427 \mathrm{~kg} \mathrm{ha}^{-1}$, while treatment 1 had a mean yield of 3,547 $\mathrm{kg} \mathrm{ha}^{-1}$ during the same period, that is, above the mean yield in the state of Paraná. It shows that grain yield and energy output in treatment 1 were not compromised even though it is a crop succession system.

\section{Table 3}

Grain yield in the first and second crop rotationcycle in $\mathrm{kg} \mathrm{ha}^{-1}$

\begin{tabular}{|c|c|c|c|c|c|c|}
\hline Crops & \multicolumn{2}{|c|}{$2014 / 2015$} & \multicolumn{2}{|c|}{$2015 / 2016$} & \multicolumn{2}{|c|}{$2016 / 2017$} \\
\hline Treatments & Winter & Summer & Winter & Summer & Winter & Summer \\
\hline \multirow{2}{*}{1} & C & SB & C & SB & C & SB \\
\hline & 5,895 & 2,965 & 6,536 & 3,241 & 2,737 & 4,030 \\
\hline \multirow{2}{*}{2} & WO & SB & $\mathrm{R}$ & C & W & SB \\
\hline & 3,247 & 3,518 & - & 9,867 & 3,762 & 4,488 \\
\hline \multirow{2}{*}{3} & $\mathrm{BO}+\mathrm{R}$ & SB & $\mathrm{BO}+\mathrm{FR}$ & C & CG & SB \\
\hline & - & 3,431 & - & 10,300 & - & 4,591 \\
\hline \multirow{2}{*}{4} & $C L$ & C & CR & C & SF & SB \\
\hline & 1,756 & 11,202 & 1,475 & 9,252 & 1,006 & 4,397 \\
\hline \multirow{2}{*}{5} & BW/FR & C & B & SB & BW/BO & SB \\
\hline & 1,161 & 10,630 & 1,984 & 3,006 & 785 & 4,369 \\
\hline \multirow{2}{*}{6} & W & $\mathrm{C}+\mathrm{CG}$ & $C L$ & C & B & SB \\
\hline & 1,833 & 10,532 & 1,142 & 9,591 & 776 & 4,617 \\
\hline Crops & \multicolumn{2}{|c|}{$2017 / 2018$} & \multicolumn{2}{|c|}{ 2018/2019 } & \multicolumn{2}{|c|}{$2019 / 2020$} \\
\hline Treatments & Winter & Summer & Winter & Summer & Winter & Summer \\
\hline \multirow{2}{*}{1} & C & SB & C & SB & C & SB \\
\hline & 8,040 & 4,138 & 5,775 & 3,285 & 2,312 & 3,625 \\
\hline \multirow{2}{*}{2} & WO & S & TCL & C & W & SB \\
\hline & 3,369 & 4,268 & 3,401 & 8,802 & 3,842 & 3,864 \\
\hline \multirow{2}{*}{3} & $\mathrm{BO}+\mathrm{R}$ & S & $\mathrm{BO}+\mathrm{FR}$ & M & CG & SB \\
\hline & - & 4,231 & - & 8,761 & - & 3,848 \\
\hline \multirow{2}{*}{4} & $C L$ & C & CR & C & $C L$ & SB \\
\hline & 367 & 10,649 & - & 8,630 & 1,084 & 4,027 \\
\hline \multirow{2}{*}{5} & BW/FR & C & B & S & BW/BO & SB \\
\hline & 1,654 & 11,502 & 1,851 & 3,448 & 2,578 & 3,650 \\
\hline \multirow{2}{*}{6} & W & $\mathrm{C}+\mathrm{CG}$ & $\mathrm{CL}$ & C & B & SB \\
\hline & 4,046 & 10,340 & 1,282 & 7,915 & 2,337 & 4,068 \\
\hline
\end{tabular}

W - wheat; SB - Soybean; WO - White oat; BO - black oat; C - Corn; B - bean; FR - fodder radish; R - Rye; CR - crambe; SF - safflower; CL - canola; BW - buckwheat; CG - congo grass; TCL - triticale "-" there was no Harvest. 
Canola also had a low mean grain yield in the 2016 and 2017 growing seasons in treatment $4\left(1,006\right.$ and $367 \mathrm{~kg} \mathrm{ha}^{-1}$, respectively) compared to the mean yield in the state of Paraná $\left(1,833\right.$ and $1,200 \mathrm{~kg} \mathrm{ha}^{-1}$, respectively) (CONAB, 2021). A harvest of crambe was lost in this treatment, which may have interfered with its energy output. The same occurred with wheat in the 2014 growing season, which had a grain yield of $1,833 \mathrm{~kg} \mathrm{ha}^{-1}$, and bean in the 2016 growing season, with a grain yield of $776 \mathrm{~kg} \mathrm{ha}^{-1}$, while the mean yield in the state of Paraná reached 2,732 and 1,355 $\mathrm{kg} \mathrm{ha}^{-1}$ in these seasons for wheat and bean, respectively (CONAB, 2021). The yield of corn grown in the summer is another factor that can be observed in the studied treatments by comparing treatments $2,3,4,5$, and 6 (Table 3) with the mean yields in the state of Paraná in the $2014 / 2015\left(8,640 \mathrm{~kg} \mathrm{ha}^{-1}\right), 2015 / 2016$
(7,937 kg ha-1), 2017/2018 (8,748 kg ha-1), and $2018 / 2019$ growing seasons $(8,833 \mathrm{~kg}$ $\mathrm{ha}^{-1}$ ) (CONAB, 2021), only T6 in the $2018 / 2019$ growing season had a lower mean corn yield compared to that observed in the state of Paraná, the other mean yields were close to or much higher than the means in the state of Paraná, showing that the energy output in these systems was high due to the high yields of summer corn.

Table 4 shows the sums of total input and output energies, the energy balance in $\mathrm{MJ}$ $\mathrm{ha}^{-1}$ of treatments with crop rotation, and the energy efficiency of each one of them. The treatments had high energy efficiency, all with values above 1.0. According to Quesada and Beber (1990), efficiency values higher than 1.0 represents a positive balance, while values lower than 1.0 represent a negative balance.

\section{Table 4}

Total inputs and outputs ( $\left.\mathrm{MJ} \mathrm{ha}^{-1}\right)$, energy balance ande energy efficiency of six tears of crop rotation. Londrina-PR

\begin{tabular}{|c|c|c|c|c|}
\hline Treatments & $\begin{array}{l}\text { Energy inputs } \\
\qquad\left(\mathrm{MJ} \mathrm{ha}^{-1}\right)\end{array}$ & $\begin{array}{l}\text { Energy outputs } \\
\qquad\left(\mathrm{MJ} \mathrm{ha}^{-1}\right)\end{array}$ & $\begin{array}{l}\text { Energy balance } \\
\qquad\left(\mathrm{MJ} \mathrm{ha}^{-1}\right)\end{array}$ & Energy Efficiency \\
\hline T1 & $91,058.46$ & $877,381.15$ & $786,322.69$ & 9.64 \\
\hline T2 & $100,624.11$ & $836,436.39$ & $735,812.28$ & 8.31 \\
\hline T3 & $58,792.58$ & $587,100.01$ & $528,307.43$ & 9.99 \\
\hline T4 & $93,445.08$ & $959,887.35$ & $866,442.27$ & 10.27 \\
\hline T5 & $85,246.76$ & $675,301.09$ & $590,054.33$ & 7.92 \\
\hline T6 & $107,765.08$ & $933,729.47$ & $825,964.39$ & 8.66 \\
\hline
\end{tabular}

Energy balance $=\Sigma$ total energy of produced products $-\sum$ non-renewable energy inputs.

Energy efficiency $=\Sigma$ total energy of produced products $/ \Sigma$ non-renewable energy inputs.

Treatments T4 and T6 showed the highest energy balances, as they are the only systems with four corn cultivations in the summer, two soybean cultivations, and higher diversification of commercial winter crops. On the other hand, T3 had the lowest energy balance and was also the system that had the lowest energy input and output. It is due to 
the exclusive cultivation of soil cover plants in the winter, which are not fertilized and have few cultural treatments, resulting in low use of machines in their growing cycle, in addition to not being used for grain harvesting. T4 T3, and T1 had the highest energy efficiency indices, with values of 10.27, 9.99, and 9.64, respectively, indicating an energy return of 9.27, 8.99, and 8.64, respectively, for each unit of energy invested for producing in these systems. These treatments were followed by T6, T2, and T5, with efficiency values of 8.66, 8.31 , and 7.92 , respectively.

Treatment T4 had the highest energy balance and the highest energy efficiency index. This treatment had four corn cultivations in the summer during the six years of crop rotation. Corn increased the energy balance of this system and, consequently, increased the energy efficiency index, which reached 15.34, 13.23, 31.91, and 11.88 in the summers of the $2014 / 2015,2015 / 2016$, 2017/2018, and 2018/2019 growing seasons, respectively. Soybean had indices of 12.83 in the 2016/2017 growing season and 12.14 in the 2019/2020 growing season. For winter crops, canola presented indices of 9.14, 1.01, and 5.17 in the 2014, 2017, and 2019 growing seasons, respectively, crambe had indices of 4.65 and 0 in the 2015 and 2018 growing seasons, respectively, and safflower reached a value of 2.82 in the 2016 growing season.

Treatment T3 presented the secondhighest energy efficiency index although this treatment uses soil cover plants in the winter cultivation (rye + black oat, black oat + forage radish, and signalgrass), with no grain harvesting and, therefore, with negative energy efficiencies and balances. Two corn and four soybean cultivations in the summer compensated for these negative efficiency values, especially corn in the summer due to its high energy conversion. This system is characterized by improving the physical, chemical, and biological soil quality and, according to Pereira et al. (2011), conservation management systems that aim to improve these soil characteristics cause changes in the root distribution in subsequent cultivations and directly interfere with the shoot growth and, consequently, crop yield.

Treatment T1 showed the third-highest energy efficiency. This place is also due to the corn crop, which had a higher energy efficiency than the other winter cultivations of the other treatments. Therefore, the corn grown both in the winter and in the summer boosted energy efficiency in T4, T3, and T1. Santos et al. $(2001,2003)$ mentioned that crop rotation systems with better energy efficiency indices are those with corn due to their higher energy conversion indices. Santos, Ignaczak, Lhamby and Baier (2000a) also reported the importance of corn for the system because this crop provided a decrease in its energy conversion values when not harvested. Santos et al. (2000b) evaluated the conversion and energy balance of grain production systems with annual winter pastures for six years under a no-tillage system and verified that the wheat/ soybean and black oat + vetch/corn and wheat/ soybean, black oat pasture + vetch/soybean and black oat pasture + vetch/corn obtained better energy efficiency. According to the authors, the inclusion of corn as a component in the systems would be the reason why they present higher energy efficiency indices, indicating the importance and potential of corn as an energy converter.

Treatment T6 had the second-highest energy balance but had the fourth highest energy efficiency. It can be explained by 
winter cultivations of wheat, canola, and bean, which showed low grain yields in the first crop rotation cycle and, consequently, low energy conversion. Also, the bean crop had a negative energy efficiency of 0.96 in the 2016 growing season of this system, according to Quesada and Beber (1990).

Treatment T5, with two corn cultivations and four soybean cultivations in the summers, had the lowest energy efficiency index among all adopted systems (Table 4). It occurred because the bean crop presented low energy efficiency, with a value of 2.69 in the 2015 growing season and 2.49 in the 2018 growing season, while buckwheat/fodder radish or white oat cultivations had a negative energy balance in the $2014(-3,819.92 \mathrm{MJ}$ $\left.\mathrm{ha}^{-1}\right), 2016\left(-7,956.26 \mathrm{MJ} \mathrm{ha}^{-1}\right)$, and 2019 growing seasons $(-1,033.87 \mathrm{MJ} \mathrm{ha-1})$, and energy efficiency values of $0.30,0.12$, and 0.78 , respectively, which means a negative efficiency. Buckwheat/turnip presented an energy balance of $255.94 \mathrm{MJ} \mathrm{ha}^{-1}$ and an energy efficiency of 1.12 in the 2017 growing season, but it can be considered as low energy efficiency.

All treatments had positive energy balance and efficiency even with the ups and downs of the systems, that is, they produced more energy than they consumed. Therefore, they can be considered sustainable systems from an energy point of view.

The second corn crop/soybean succession system is sustainable only from an energy point of view, because from an environmental perspective, the traditional system may not present sustainable physical, chemical and biological soil quality characteristics, as observed in the rotation systems of cultures(Franchini, Costa, \&Debiasi,
2011). In the economic aspect, the soybean/ maize second crop succession system is also not advantageous, as evidenced by Volsi, Higashi, Bordin and Telles (2021), who when analyzing the same experiment, verified that crop rotation systems are economically more profitable than corn second crop/soybean succession. Volsi, Bordin, Higashi and Telles (2020), when studying succession systems and crop rotation in the fall sandstone, also found that the system with greater crop diversification was more profitable than less diversified systems.

Any agricultural activity aims to achieve maximum profit. However, the production viability of a system does not only depend on the harvest yield and the product value at commercialization but also its efficiency in the use of available resources. Although the agricultural systems compared in this study are dependent on fossil and non-renewable energy, they are capable of being efficient, presenting an energy return approximately nine times higher than what is consumed. However, in addition to profitable production systems, they should be efficient, rational, and environmentally and energetically sustainable.

\section{Conclusions}

The studied systems showed positive energy balance and efficiency, that is, they produced more energy than they consumed.

The canola/corn, crambe/corn, and canola/soybean rotation systems presented the highest energy balance and efficiency, with values of $866,442.27 \mathrm{MJ} \mathrm{ha}^{-1}$ and 10.27, respectively, mainly due to corn cultivation in the summer, which resulted in a higher energy return than the other grain-producing crops. 


\section{Acknowledgments}

The authors would like to thank the IBITIBA project at ITAIPU-Binacional, the agricultural technician Nelcir Aparecido Rodrigues, and Dr. Hevandro Colonhese Delalibera for their support during the development of this study. The last author is grateful to CNPq for the fellowship (30580/2018-2).

\section{References}

American Society of Agricultural Engineers (2003). American Society of Agricultural Engineers. St. Joseph, MI: Author.

Assenheimer, A., Campos, A. T., \& Gonçalvez Júnior, A. C. (2009). Análise energética de sistemas de produção de soja convencional e orgânica. Ambiência, 5(3), 1-13. Retrieved from http://repositorio. ufla.br/jspui/handle/1/11586

Bueno, O. C. (2002). Análise energética e eficiência cultural do milho em assentamento rural, Itaberá/SP. Tese doutorado, Universidade Estadual Paulista, Botucatu, SP, Brasil. Retrieved from http://hdl.handle. net/11449/101905

Campos, A. T., Klosowsk, E. S., Souza, C. S., Zaninu, A., \& Prestes, T. M. V. (2009). Análise energética da produção de soja em sistema de plantio direto. Global Science Technology, 2(2), 38-44. Retrieved from https://rv.ifgoiano.edu.br/periodicos/ index.php/gst/article/view/43

Companhia Nacional de Abastecimento (2021). Portal de informações agropecuárias: produção agrícola. Brasília: CONAB. Retrieved from https:// portaldeinformacoes.conab.gov.br/safraserie-historica-graos.html

Ferreira, F. F., Neumann, O. S., \& Hoffmann, R. (2014). Análise da matriz energética e econômica das culturas de arroz, soja e trigo em sistemas de produção tecnificados no Rio Grande do Sul. Ciência Rural, 44(2), 380-385. doi: 10.1590/ S0103-84782013005000157

Fialho, E. T., \& Albino, L. F. T. (1983). Tabela de composição química e valores energéticos de alimentos para suínos e aves. Concórdia, SC: EMBRAPACNSA. Retrieved from https://www. embrapa.br/busca-de-publicacoes/-/ publicacao/435277/tabela-de-compo sicao-quimica-e-valores-energeticosde-alimentos-para-suinos-e-aves

Franchini, J. C., Costa, J. M., \& Debiasi, H. (2011). Rotação de culturas: prática que confere maior sustentabilidade à produção agrícola no Paraná. International Plant Nutrition Institute Brasil, (134), 1-28. Retrieved from http:// www.ipni.net/publication/ia-brasil.nsf/0/ d88eb80e259ba11e83257a8f005e67e 3/\$file/page1-13-134.pdf

Jasper, S. P., Biaggioni, M. A. M., Silva, P. R. A., Seki, A. S., \& Bueno, O. C. (2010). Análise energética da cultura do crambe (Crambe abyssinica hochst) produzida em plantio direto. Engenharia Agrícola, 30(3), 395-403. doi: 10.1590/S0100-691 62010000300004

Khakbazan, M., Mohr, R. M., Huang, J., Xie, R., Volkmar, K. M., Tomasiewicz, D. J.,... Nelson, A. (2019). Effects of crop rotation on energy use efficiency of irrigated potato withcereals, canola, and alfalfa over 
a 14-year period in Manitoba, Canadá. Soil \& Tillage Research, 195, 1-12.. doi: 10.1016/j.still.2019.104357

Marchioro, N. P. X. (1985). Balanço ecoenergético: uma metodologia de análise de sistema agrícola. Curitiba, PR: Fundação Instituto Agronômico do Paraná.

Medeiros, G. B., \& Calegari, A. (2006). Rotação de culturas. In: Casão Júnior, R., Metha, Y.R. \& Passini, J. J. Sistema plantio direto com qualidade (pp. 135-142). Londrina, PR: IAPAR.

Medeiros, L. F. S. (2011). Avaliação de energia contida nos principais sistemas agrícolas e industriais da região médio norte do estado de Mato Grosso. Dissertação de mestrado, Universidade Federal do Mato Grosso, Cuiabá, MT, Brasil.

Müller, J., Levien, R., Mazurana, M., Alba, D., Conte, O., \& Zulpo, L. (2017). Energy balance in crop-farming system under soil management and cover crops. Agrária, 12(3), 348-353. doi: 10.5039/agraria.v12 i3a5463

Nitsche, P. R., Caramori, P. H., Rice, W. S., \& Pinto, L. F. D. (2019). Atlas climático do estado do Paraná. Londrina, PR: Instituto Agronômico do Paraná. Retrieved from http://www.iapar.br/modules/conteudo/ conteudo.php?conteudo=913

Pacheco, E. P. (2000). Seleção e custo operacional de máquinas agrícolas. Rio Branco, AC: EMBRAPA. Retrieved from https://www.embrapa.br/buscade-publicacoes/-/publicacao/495355/ selecao-e-custo-operacional-de-maqui nas-agricolas
Pereira, R. G., Albuqueque, A. W., Souza, R. O., Silva, A. D., Santos, J. P. A., Barros, E. S., \& Medeiros, P. V. Q. (2011). Sistemas de manejo do solo: soja [glycine max (I.)] consorciada com Brachiaria Decumbens (STAPF). Pesquisa Agropecuária Tropical, 41(1), 44-51. doi: 10.5216/pat.v41i1.6981

Pimentel, D. (1980). Handbook of energy utilization in agriculture. Boca Raton, Florida: CRC, Press Inc.

Pimentel, D., Berardi, G., \& Fast, S. (1983). Energy efficiency of farming systems: organic and conventional agriculture. Agriculture, Ecosystems and Environment, 9(4), 359372. doi: 10.1016/0167-8809(83)90021-X

Quesada, G. M., \& Beber, J. A. C. (1990). Energia e mão-de-obra. Ciência Hoje, 11(62), 21-26. In: Santos, H. P., Ignaczak, J. C., Lhamby, J. C. B., \& Baier, A. C. (2000). Conversão e balanço energético de sistemas de rotação de culturas para triticale, sob plantio direto. Ciência Rural, 30(1), 43-48. doi: 10. 1590/S010384782000000100007

Riquetti, N. B., Benez, S. H., \& Silva, P. R. A. (2012). Demanda energética em diferentes manejos de solo e híbridos de milho. Revista Energia na Agricultura, 27(2), 76-85. doi: 10.17224/EnergAgric 2012v27n2 p76-85

Risoud, B. M. (1999). Développement durable et analyse énergétique d'exploitations agricoles. Économie Rurale, 252, 16-27. Retrieved from https://www.persee.fr/ doc/ecoru_0013-0559_1999_num_252_ $1 \_5096$

Romanelli, T. L. (2002). Modelagem do balanço energético na alimentação suplementar para bovinos. Dissertação de mestrado, 
Escola Superior de Agricultura Luiz de Queiroz, Piracicaba, SP, Brasil.

Santos, H. G., Jacomine, P. K. T., Anjos, L. H. C., Oliveira, V. A., Lumbreras, J. F., Coelho, M. R., Cunha, T. J. F. (2018). Sistema brasileiro de classificação de solos. Brasília, DF: EMBRAPA. Retrieved from https://www. embrapa.br/solos/sibcs

Santos, H. P., Fontaneli, R. S., Ignaczak, J. C., \& Zoldan, S. M. (2000b). Conversão e balanço energético de sistemas de produção de grãos com pastagens sob plantio direto. Pesquisa Agropecuária Brasileira, 35(4), 743-752. doi: 10.1590/ S0100-204X2000000400010

Santos, H. P., Ignaczak, J. C., Lhamby, J. C. B., \& Baier, A. C. (2000a). Conversão e balanço energético de sistemas de rotação de culturas para triticale, sob plantio direto. Ciência Rural, 30(1), 43-48. doi: 10.1590/ S0103-84782000000100007

Santos, H. P., Ignaczak, J. C., Lhamby, J. C. B., \& Carmo, C. (2003). Conversão e balanço energético de sistema de manejo de solo e de rotação de culturas. Pesquisa Agropecuária Gaúcha, 9(1-2), 113119. Retrieved from http://revistapag. agricultura.rs.gov.br/ojs/index.php/ revistapag/article/view/467

Santos, H. P., Lhamby, J. C. B., Ignaczak, J. C., \& Schneider, G. A. (2001). Conversão e balanço energético de sistemas de sucessão e de rotação de culturas. Ciência Rural, 31(2), 191-198. doi: 10. 1590/S0103-84 782001000200001
Santos, H. P., Spera, S. T., Fontaneli, R. S., \& Dreon, G. (2011). Avaliação de práticas culturais na conversão e no balanço energético. Agrária, 6(4), 634-641. doi: 10.5039/agraria.v6i4a1366

Santos, H. P., Tomm, G. O., Spera, S. T., \& Ávila, A. (2007). Efeito de práticas culturais na conversão e no balanço energéticos. Bragantia, 66(2), 299-306. doi: 10.1590/ S0006-87052007000200014

Santos, R. R. (2006). Análise energética do milho em sistemas de plantio direto, em assentamento rural, Itaberá/SP. Dissertação de mestrado, Universidade Estadual Paulista Júlio de Mesquita Filho, Botucatu, SP. Brasil.

Santos, R. R., \& Simon, E. J. (2010) Análise energética do milho em sistema de plantio direto, no assentamento rural da fazenda Pirituba, Itaberá/SP. Energia na Agricultura, 25(1), 121-137. doi: 10.17 224/EnergAgric.2010v25n1p121-137

U. S. Department of Agriculture (2019). FoodData Central. Washington D.C.: USDA. Retrieved from fdc.nal.usda.gov

Volsi, B., Bordin, I., Higashi, G. E., \& Telles, T. S. (2020). Economic profitability of crop rotation systems in the Caiuá sandstone area. Ciência Rural, 50(2), 1-11. doi: 10. 1590/0103-8478cr20190264

Volsi, B., Higashi, G. E., Bordin, I., \& Telles, T. S. (2021). Production and profitability of diversified agricultural systems. Anais da Academia Brasileira de Ciências, 93(2), 1-15. doi: 10.1590/0001-376520212019 1330 